\title{
Effect of Foreign Direct Investment (FDI) On Manufacturing Output In Nigeria (1981 - 2016).
}

\author{
Dr. Cletus Usman Idoko \\ Department of Economics, \\ Kogi State University, Anyigba. \\ Usio Uchechi Taiga \\ Department of Economics, \\ Kogi State University, Anyigba.
}

\begin{abstract}
This study examined the effect of Foreign Direct Investment (FDI) on manufacturing sector output growth in Nigeria for the period of 1981 to 2015. The research was guided by two research questions and objectives. The Vector Auto Regression (VAR) technique and Johansen Co-integration test were employed for testing the hypotheses of the study. The VAR analysis empirical results from the impulse response function and variance decomposition test shows that FDI had a positive but minimal effect on the manufacturing sector output in Nigeria. The Co-integration test results show that there exist a long-run relationship between FDI and the manufacturing sector output growth in Nigeria. To improve on the gains of FDI on the manufacturing sector, the study recommends that government should carryout infrastructural development, like power supply to improve the absorptive capacity of manufacturing firms.Also there should be a clear guideline in government policy regarding priority sectors such as the manufacturing sector where foreign investments should be directed in the country.It was also recommended that effort should be made to increase productivity in the manufacturing sector by upgrading its technologies; and on the issue of corruption and diversion of funds, among others were proffered.
\end{abstract}

Keywords: Foreign Direct Investment, Manufacturing, Exchange rate, Corruption, Nigeria.

\section{INTRODUCTION}

Foreign direct investment are the net inflows of investment to acquire a lasting management interest (10 percent or more of voting stock) in an enterprise operating in an economy other than that of the investor. It is an investment made by a country, in the form of either establishing business operations or acquiring business assets in the other country, such as ownership or controlling interest in a foreign company.In most developed and developing countries today, one of the major channels of achieving a rapid economic development, is to attract Foreign Direct Investment (FDI) in different sectors of the economy, most especially in the manufacturing sector because of its well-known economic advantages. FDI provides much needed resources to developing countries such as capital, technology, managerial skills, entrepreneurial ability, brands, and access to markets, as they are essential for developing countries to industrialize, develop, and create jobs attacking the poverty situation in their countries (Chenery\&Strout, 1966).

Maji\&Achegbulu (2011) stated that the possibilities of achieving rapid and sustained development through effective use of FDI have been applied and demonstrated by countries 
like Singapore, Hong Kong and Thailand. With this, these countries today are known among other countries as the developed and industrialized countries in the world.

Nigeria as the largest economy in Africa has attracted significant amount of FDI inflow in recent years. The foreign direct investment inflow in Nigeria increased from $\$ 193.2$ million in 1986 to $\$ 1874.04$ billion in 2002. For the periods of 2003 to 2013, it further rose from $\$ 2005.4$ billion to $\$ 5609$ billion. The inflow of FDI as the percentage of GDP increased from 0.93 percent in 1986 to 5.05 percent in 2009 but later declined to 1.64 percent in 2010 and 1.07 percent in 2013 (UNCTAD, 2015).

However, according to UNCTAD (2015), Nigeria saw its FDI inflow decline from 2010 to 2015 by $27 \%$ to $\$ 3.4$ billion as the nation was hard hit by the global drop in oil price, against this backdrop she accounted for about 6\% of FDI inflow to Africa and received approximately 31\% of the sub-regional total, with the oil and gas sector alone receiving about $70 \%$ of the FDI inflow. This was as a result on the fact that FDI over the years domiciled mainly in the now gloomy oil sector in Nigeria, hence contributing to the underdevelopment of the manufacturing sector.

The sudden drop of FDI inflows in 2010 took place due to recent events that occurred during the past administration. Among the events majorly was the present of socio-political upheaval from some anti-social group known as the "BokoHaram Sect" in the country especially in the Northeast which is highly detrimental to the growth and health of the nation's economy. Okoli\&Agu (2015) opined that the presence of the terrorists - BokoHaram was a kind of a snail movement of the development process and eventually a complete overhauling of the entire system, lack of industrialization, capital flight and absence of technology transfers. This makes the country economically unfriendly and non-conducive for investors to thrive. Because, no investor will like to invest in a place where he will suffer capital loss no matter how promising it will appear.

Therefore, it is evident that if a host country like Nigeria creates a conducive and friendly macroeconomic environment for investors, FDI can play a crucial role in the manufacturing sector which will carve out potential benefits which include employment generation, promotion of citizen's welfare and economic growth by providing additional capital to the host country, stabilizing exchange rate, supplementing domestic savings and transfer of modern technology.

\section{Statement of the Problem}

The manufacturing sector in Nigeria is seen to be tied to foreign investments because of the purchase of capital equipment in other to facilitate growth and development process. This has been a success in Nigeria until the early 1980s, when oil market that was the major source of the nation's foreign earnings collapsed due to fall in prices. As a result, there was a reduction of foreign investments gotten from the exportation of oil. This could not provide the necessary stimuli for the growth and development in the manufacturing sector (Akinmulegun\&Oluwole, 2013).

Various policy measures by government in Nigeria have been adopted in other to rectify the problems associated with the country's foreign earnings, but little was achieved. Among these policies include the Restrictive Monetary Policy, the Stabilization Measure of 1982 and the Stringent Measure of 1984, as well as the Structural Adjustment Programme (SAP) of 1986 whose aim was to reduce the high dependency of crude oil as a major foreign exchange earner by promoting non-oil exports especially the manufacturing products in the economy 
(Okoli\&Agu, 2015). However, with the pursuant of these policies, Nigeria still recorded the second largest recipient of FDI inflows among low-income countries (CBN, 2010).

It is important to note thatvarious factors are impeding the flow of FDI in the Nigerian economy, which has made other sectors mostly the manufacturing sector to suffer, as the level of productivity and performance seems to be very low and poor. These factors include: the present of social-political upheaval from some anti-social group/terrorists known as the "Boko-Haram Sect", insufficient human capital skills, poor management of resources, weak or inadequate infrastructure, corruption, political instability, and poor technological base to support the growth of manufacturing activities and obsolete machinery and equipment (Opaluwa, et al, 2012; Okoli\&Agu, 2015; Fabayo, 2003; Eboh, 2011; Nnanna, et al, 2004).

Therefore, in the light of the above, this study examines the effect of FDI on the growth of the manufacturing sector output in Nigeria.

\section{Research Questions}

Based on the above assertions, the following research questions guided the study;

i. $\quad$ what is the effect of FDI inflow on the manufacturing sector output in Nigeria?

ii. is there a long-run relationship between FDI and the manufacturing sector output in Nigeria?

\section{Objectives of the Study}

The objectives of the study are:

i. toexamine the effect of FDI inflow onthe manufacturing sector output in Nigeria.

ii. toexamine the long-run relationship between FDI and the manufacturing sector output in Nigeria.

\section{Research Hypotheses}

The following hypotheses are tested:

i. $\mathrm{H}_{0}$ : there is no effect of FDI inflow on themanufacturing sector output in Nigeria. $\mathrm{H}_{1}$ : there is effectof FDI inflow on the manufacturing sector output in Nigeria.

ii. $\mathrm{H}_{0}$ : there is no long-run relationship between FDI and the manufacturing sector output in Nigeria.

$\mathrm{H}_{1}$ : there is long-run relationship between FDIand the manufacturing sector outputin Nigeria.

\section{Scope of the Study}

This study assessed the effectof FDI on the manufacturing sector output in Nigeria. The study was restricted to the period between 1981 and 2016 using relevant indicators such as Foreign Direct Investment (FDI), Manufacturing Output (MFO), Exchange rate (EXH), Inflation rate (INF), and Capacity Utilization rate (CAPU), which the data was sourced from Central Bank of Nigeria (CBN) statistical bulletins (2016) and National Bureau of Statistics (2016).

\section{CONCEPTUAL LITERATURE}

Foreign direct investment is the sum of equity capital, reinvestment of earnings, other longterm capital, and short-term capital as shown in the balance of payments.Glass and Saggi (2009) contributes that foreign direct investment alludes to a development of capital that includes possession and control of a firm in another nation. Uzoka (2012) posited that foreign direct investment is the inflow of outside salary into a specific economy through speculation which includes multinational enterprises. Foreign Direct Investments (FDI), in addition to migration and capital transfers, is one of the ways in which nations of the world experience 
international exchange of capital, labour and productivity factors; it involves the investment of resources by individuals, companies or government of one country in the economy of another. On the other hand, the manufacturing sector is a subset of the industrial sector (processing, quarrying, craft and mining) which involves the conversion of raw materials into finished consumer goods or intermediate or producer goods. The manufacturing sector creates avenue for employment, helps to boost agriculture and diversify the economy while it helps the nation to increase its foreign exchange, thus, helping local labour to develop skills. It minimizes the risk of over dependence on foreign trade and leads to optimum utilization of available resources. As posited by Obichukwu(2013), manufacturing output is what an industry produces as a national total output in spite of its present poor performance, which also act as major sources of hope for sustainable growth and development in Nigeria.

In relation to the Nigerian manufacturing sector, Ayanwale (2007) studied the effects of foreign direct investment on the performance of the Nigerian manufacturing sector, and revealed that the country is striving to attract more foreign investors. This is so because the revenue gained through these investments can support the operations and activities of the manufacturing sector. However, available statistics of the Nigeria's manufacturing and macroeconomic data as generated in the study of Ehijiele, et al (2015) did not paint a good picture of manufacturing production in Nigeria as at 2015, as the manufacturing production in Nigeria decreased to 0.30 percent in June of 2015 over the same month in the previous year in 2014. Manufacturing Production in Nigeria averaged 8.43 percent from 2007 until 2015, reaching an all-time high of 24.60 percent in the fourth quarter of 2013 and a record low of -0.70 percent in the first quarter of 2015.

In addition, the study of Ayanwale (2007) brought to light that while foreign investments in manufacturing could be beneficial to the economy, it is necessary that human resource issues are resolved as well so that the financial resources can be effectively utilized. Imoudu (2012) submits that there has been some diversification into the manufacturing sector in recent years, although FDI in Nigeria has traditionally been concentrated in the extractive industries. He further stated that the manufacturing and processing sector received enormous attention within the period of 1980-2009. In 1980-84, its share of total FDI stood at 38.3 percent; it reaches the peak of 43.7 percent between the periods 1990-94, fell to 23.6 percent in 1995-99 and rose to 40.7 percent in 2005-09. Its average total all through the period was, however, 34.8 percent in 1980-2009. This result is in conformity with Fabayo (2003) that the manufacturing sector attracts more FDI than other sectors of the economy.

However, many problems are hindering the growth of the manufacturing sector in Nigeria and as a result the country is progressing very slowly towards economic diversification. Dipak and Ata (2003) summed up the economic scenario in Nigeria and the role of the manufacturing sector by identifying the main hurdles that mostly and historically affect its development and growth. These barriers include practice of mono-economy (over dependency on the oil sector), insecurity, political instability, market-distorting, state-owned monopolies, weak infrastructure and unavailability of finance while Adenikinju (2003) added excessive bureaucracy and rampant corruption.

\section{THEORETICAL FRAMEWORK OF THE STUDY}

The Endogenous Growth model (AK-model and Cobb Douglas Production function) serves as the theoretical base for this study.

The AK-model, which is the simplest endogenous model, gives a constant savings rate of endogenous growth and assumes a constant, exogenous, saving rate. It models technological 
progress with a single parameter (usually A). It uses the assumption that the production function does not exhibit diminishing returns to scale to lead to exogenous growth. Various rationales for this assumption have been given, such as positive spillovers from capital investment to the economy as a whole or improvements in technology leading to further improvements. However, the endogenous growth theory is further supported with models in which agents optimally determined the consumption and saving, optimizing the resources allocation to research and development (R\&D) leading to technological progress (Romer, 1987, 1990; Aghion\&Howith, 1992; and Grossman \&Helpman, 1991).

The AK model production function is a special case of a Cobb-Douglas function with constant returns to scale.

$$
Y=A K^{a} L^{1-a}
$$

This equation shows a Cobb-Douglas function where $Y$ represents the total production in an economy. Arepresent total factor productivity, $K$ is capital, $L$ is labour, and the parameter $a$ measures the output elasticity of capital. For the special case in which $a=1$, the production function becomes linear in capital and does not have the property of decreasing returns to scale in the capital stock, which would prevail for any other value of the capital intensity between 0 and 1.

In an alternative form $Y=A K, K$ embodies both physical capital and human capital.

$$
Y=A K
$$

In the above equation $A$ is the level of technology which is positive constant and $K$ represents volume of capital. Hence, output per capital is:

$$
\frac{Y}{L}=A \cdot \frac{K}{L}, \text { i.e } \mathcal{Y}=A K
$$

The model implicitly assumes that the average product of capital is equal to marginal product of capital which is equivalent to:

$$
A>0
$$

\section{EMPIRICAL LITERATURE}

Chandran and Krishnan (2008) used the Autoregressive Distributed Lag (ARDL) approach toexamine the short and long run dynamics of foreign direct investment (FDI) over the manufacturing growth in Malaysia for the period of 1970 - 2003 with data sourced from World Bank development indicators. The study revealed that FDI elasticity in the short and long run were found to be statistically significant. The study also revealed that strategies are to be developed to enhance the competitiveness of Malaysian manufacturing sectors in the world of intense competition for FDI.

Ebekozien, Ugochukwu and Okoye (2015) employed simple percentages, regression analysis, Duncan Multiple Range Test and Granger Test to analyse the effect of inflow trends of Foreign DirectInvestment in the Nigerian construction industry with data sourced from the central bank of Nigeria and the National Bureau of Statistics served, and revealed that there is poor flow (or an insignificant flow) of FDI into construction sector when compared to other sectors of the economy. 
Anowor, Ukweni, Ibiam, \&Ezekwem (2013) employed the OLS estimation technique to analyze the contributions of foreign direct investment to the growth of manufacturing sector in Nigeria using annual time series data from 1970 to 2011, with data sourced from Central Bank of Nigeria (CBN) Statistical Bulletins of 2012, which revealed that FDI was related and statistically significant to manufacturing sector output growth among other variables such as the exchange rate, degree of trade openness and domestic investment.

Okoli and Agu (2015) employed the OLS and VECM techniques to assess the impact of foreign direct investment flow on the performance of the manufacturing firms in Nigeria spanning for a period of 40 years, with data sourced from World Bank and CBN bulletins, which revealed that FDI inflows had a positive impact only in the long-run. The results obtained suggest the need for government actions to be geared towards strategically maintaining and sustaining policies that will help encourage FDI inflows to promote an efficient and enabling macroeconomic environment on which manufacturing firms can thrive.

Patience (2011) examines the impact of foreign direct investment on manufacturing output growth of West Africa. The study is conducted across the Economic community of West African States (ECOWAS) which is the most popular regional economic community in Africa. Data was collected from banks annual reviews. It was found that foreign direct investment contributes to manufacturing output growth in West Africa.

Ayanwale (2007) employed the OLS technique to investigate the empirical relationship between non-extractive FDI and economic growth in Nigeria spanning from 1975 to 2006 with relevant data sourced from National Bureau of Statistics and Central Bank of Nigeria statistical bulletins, which revealed that FDI has a positive link with economic growth. However, he cautioned that the overall effect of FDI on economic growth may not be significant.

Osisanwo (2013) employed the ordinary least square (OLS) method toanalyse the impact of foreign direct investment on manufacturing outputgrowth in Nigeria between a decade after independence (1970) and 2011 with data sourced from the CBN bulletins, which revealed that the first lag of real manufacturing output level (MANt-1) and inflation (INF) are significant factors influencing the growth rate of Nigerian manufacturing industry, while manufacturing output is insignificantly and inelastic of foreign direct investment in Nigeria.

Sola, Obamuyi, Adekunjo, \&Ogunleye(2013) employed the panel data analysis to examine the manufacturing performance for sustainable economic development in Nigeria from 1980 to 2008 with various data obtained from National Bureau of Statistics (NBS), which recorded a positive relationship between manufacturing and capacity utilization; a negative relationship between manufacturing and investment rate, exchange rate, and export. The study suggest that the provision of incentives for firms to become more export oriented.

Taiga (2012) used the ordinary least square (OLS) method to ascertain the relationship between manufacturing and economic growth in Nigeria from 1990 to 2010, with relevant data sourced from various issues of National Bureau of Statistics and Central Bank of Nigeria (CBN) Statistical Bulletins, which revealed that the manufacturing sector output contributed positively to real gross domestic product growth. He suggested that there should be a reduction in interest rate to encourage more investment in the economy which will boost the economy growth of Nigeria.

Li and Liu (2005) use the panel data of 84 countries to investigate the influence of FDI and economic growth spanning from 1990 to 2004 with relevant data sourced from World Bank's 
World Development Indicators, which revealed a significant relationship between FDI and economic growth. Additionally, a stronger relationship was extracted when FDI is interacted with human capital. The same conclusion emerged in the study of Kiong\&Jomo (2005) who examined the influences of FDI on Malaysian economy. However, while positive effects of FDI on growth were found, the study cautioned that the net effect of FDI could be limited when FDI affects the domestic saving rate negatively.

Adejumo (2013) used the autoregressive lag distribution technique to determine the relationship between FDI and manufacturing value added in Nigeria between the period 1970 and 2009 with data sourced from various issues of Central Bank of Nigeria (CBN) statistical bulletins and National Bureau of Statistics (NBS), which was revealed that in the long run, foreign direct investments have had a negative effect on the manufacturing sub-sector in Nigeria.

Orji, Anthony-Orji, Nchege, \&Okafor (2015), employed the classical linear regression model and with relevant data sourced from Central Bank of Nigeria (CBN) statistical bulletins, they examined the impact of FDI on the Nigeria manufacturing sector over the period of 1970 to 2010, which revealed that FDI impacted negatively on the manufacturing sector. Based on the results, they suggested that the unhealthy relationship can be reversed if the country receives increased FDI inflows into critical sectors that support the necessary inputs and raw materials needed by the local industries.

From the empirical review, it was discovered from the research work conducted by Li \& Liu (2005), Kiong and Jomo (2005), Chandran and Krishnan (2008), Patience (2011), Sola, et al (2013), Anoworet al (2013), Ebekozien, et al (2015), Okoli and Agu (2015), Osisanwo (2013), Taiga (2012), Orji, et al (2015), and Adejumo (2013) that there was more emphasis made on effect analysis of FDI on economic growth, and not on the manufacturing sector output and its long-run relationship.In addition, the period of previous studies was not extended to the year 2016. To overcome this shortfall on the concept of FDI, the study therefore employed the annual time series data to examine the effect and long-run relationship between FDI and manufacturing output and other explanatory variables such as exchange rate, inflation rate, and capacity utilization rate. Empirically, the study adopts the Vector Autoregression (VAR) technique to examine its significant effect among the variables, and Johansen co-integration test for long-run relationship spanning for 35 years, which was extended to 2016 (i.e. 1981 2016).

\section{METHODOLOGY}

The research method for this study adopts the Vector Auto Regression (VAR) model which wasused to examine the effect of FDI inflows on manufacturing output growth in Nigeria.

In the course of examining the effect of FDI on manufacturing output growth and economic growth in Nigeria, secondary data adopted for the analysis covered the period of 35years (1981 - 2016). In achieving the analysis of this study, the E-views econometric software version 4.0 was adopted with relevant data which was obtained from various issues of Central Bank of Nigeria (CBN) statistical bulletin and National Bureau of Statistics (NBS).

\section{Model Specification}

By adopting the endogenous growth theoretical framework,let the country's production be represented by the following aggregate AK production function.

$$
Y=A K
$$




$$
Y=f(A K)
$$

where $Y$ represents the total production in an economy. Arepresent total factor productivity, $K$ is the volume of capital (human \& physical capital).

With the above specification, the model adopted for this study is the Vector Auto Regression (VAR) model to determine the effect of FDI on the manufacturing sector output growth in Nigeria, the Johansen Co-integration test to estimate the long-run relationship between FDI, the manufacturing sector outputand other variables (exchange rate, inflation rate, capacity utilization rate, and interest rate); the Augmented Dickey-Fuller (ADF) testto estimate forstationarity due to the presence of unit root properties usually associated with time series data.Therefore, from equation [4] and [5], the model for this studywill be presented in equation [6] as:

$$
Y=f(\mathrm{FDI}, \mathrm{EXH}, \mathrm{INF}, \mathrm{CAPU})
$$

where $Y$ represent the manufacturing sector output (MFO) which is the function $(f)$ of foreign direct investment inflow, exchange rate, inflation rate, and the manufacturing capacity utilization rate. The incorporation of inflation and exchange rates will examine the effect of government policy framework to checkmate the commitment on the provision of infrastructures that will attract investors in the manufacturing sector, which in turn will check the level of improvement of the overall manufacturing sector output growth. The incorporation of capacity utilization rate is to examine the performance of the manufacturing sector.

Therefore, in its implicit form, Equation [6] is given in Equation [7] as:

$$
\mathrm{MFO}=f(\mathrm{FDI}, \mathrm{EXH}, \mathrm{INF}, \mathrm{CAPU})
$$

Where MFO is manufacturing output; FDI is Foreign Direct Investment; EXH is exchange rate; INF is inflation rate; and CAPU is capacity utilization rate.

The above implicit function in the model in Equation [7] can be reduced to a linear functional form as in Equation [8]:

$$
\mathrm{InMFO}=b_{0}+b_{1} \mathrm{InFDI}+b_{2} \mathrm{EXH}+b_{3} \mathrm{INF}+b_{4} \mathrm{CAPU}+\mu
$$

Where; $b_{0}$ is the intercept; $b_{1}, b_{2}, b_{3}, b_{4}$, are the coefficients of the variables; and $\mu$ is the residual or error term.

However, variables MFO and FDI were logged as InMFO and InFDI respectively in order to linearize the model and to reduce the problems of multicollinearity and heteroscedasticity in the model.The a priori expectation shall be: $b_{0}, b_{1}, b_{4},>0 ; b_{2}, b_{3},<0$.

\section{The VAR Model Specification}

According to the Economic Models at the Bank of England, the VAR approach views movements in the endogenous variables as fundamentally reflecting the effect of exogenous shocks hitting the economy. Thus, A VAR is an $n$ equation, $n$ variable model in which each variable is in turn explained by its own lagged values, plus (current) and past values of the remaining $n-1$ variables. The VAR model can be thought of as the reduced form of a dynamic economic system involving a vector of variables $Y_{t}$ as in Equation [9]. 


$$
Y_{t}=c+b_{1} Y_{t 1}+b_{2} Y_{t 2}+\ldots \ldots+b_{p} Y_{t p}+e_{t}
$$

Where $Y_{t}$ are the variables in the VAR model, $e_{t}$ is the error term, and $b_{1}, b_{2}, \ldots \ldots, b_{p}$ are the coefficient of the variables.

Therefore, Equation [8] can be expressed in VAR form as thus;

$$
\begin{aligned}
& \text { InMFO }_{t}=b_{0}+b_{1} \text { InMFO }_{t 1}+b_{2} \operatorname{InFDI}_{t 1}+b_{3} E \text { XH }_{t 1}+b_{4} I N F_{t 1}+b_{5} \text { CAPU }_{t 1}+e_{t} \\
& \text { InFDI }_{t}=a_{0}+a_{1} \text { InMFO }_{t 1}+a_{2} \text { InFDI }_{t 1}+a_{3} E \text { XH }_{t 1}+a_{4} I N F_{t 1}+a_{5} \text { CAPU }_{t 1}+e_{t}
\end{aligned}
$$

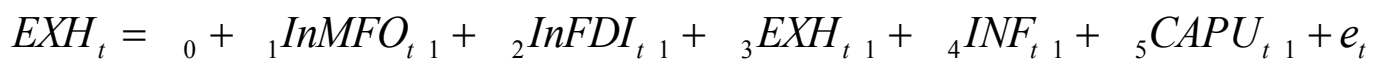

$$
\begin{aligned}
& I N F_{t}={ }_{0}+{ }_{1} I n M F O_{t 1}+{ }_{2} I n F D I_{t 1}+{ }_{3} E_{1} H_{t 1}+{ }_{4} I N F_{t 1}+{ }_{5} C A P U_{t 1}+e_{t} \\
& C A P U_{t}={ }_{0}+{ }_{1} I n M F O_{t 1}+{ }_{2} I_{n F D I} t_{1}+{ }_{3} E X H_{t 1}+{ }_{4} I N F_{t 1}+{ }_{5} C_{A P U} U_{t 1}+e_{t}
\end{aligned}
$$

Where InMFO, InFDI, EXH, INF, and CAPU are explained in Equation [7] and [8]; $b_{0}, a_{0},{ }_{0}, 0_{0},{ }_{0}$ are the intercepts of models, $b_{1}, a_{1},{ }_{1},{ }_{1},{ }_{1}$ to $\mathrm{b}_{5}, a_{5},{ }_{5},{ }_{5},{ }_{5}$ are the coefficients of the variables in the models and $e_{t}$ is the residual terms in the models.

However, in undergoing the VAR analysis, the unit root test for stationarity, co-integration test for long-run relationship among the variables, lag length analysis, VAR impulse response test and variance decomposition analysis for shock responses, stability test, and autocorrelation test will be carried out.

\section{Pre-Estimation Tests}

\section{PRESENTATION AND DISCUSSION OF ESTIMATED RESULTS}

\section{Unit Root Test Result}

The Augmented Dickey-Fuller unit root test result is presented on Appendix 2. The result shows that all the times series data employed were not stationary at level. They however became stationary at first difference.

\section{Estimating the VAR model \\ VAR Lag LengthResult}

The lag length selection criterion to determine the optimal lag structure to employ in carrying out the VAR analysis is presented on Appendix 3. This study uses the Lag length criterion based on the Schwarz Information Criterion (SIC) for its analysis. This study therefore selects 2 lags as selected by the SIC criterion for estimating the VAR and Johansen Co-integration test.

\section{Co-Integration Test Result}

The Johansen Co-integration test result used to ascertain the existence of long run relationship in the model as speculated in the second objective of this study. Its test result on Appendix 4 indicates thattrace test statistics has one co-integrating equation, while the max-eigen value statistics indicates 2 co-integrating equations at the $5 \%$ level, indicating the presence of long run relationship among the variables. Thus, this accept the alternative hypothesis that there exist a long-run relationship between FDI and the manufacturing sector growth in Nigeria. 


\section{Impulse Response Test}

The impulses represent the reactions of the variables to shocks hitting the system. However, in regards to the objective of the study, Appendix 5 shows the impulse response function result of manufacturing output growth (InMFO) to foreign direct investment (InFDI).

From Appendix 5, the impulse response of MFO to shocks from FDI indicates that for ten periods FDI has a positive but minimal effect on MFO. Thus, under the period of study, FDI has a positive but minimal effect on the manufacturing output growth in Nigeria.

\section{Variance Decomposition Test}

The test of variance decomposition for manufacturing output growth (InMFO) and foreign direct investment (InFDI) is presented on Appendix 6.

The variance decomposition of InMFO on Appendix 6 indicates that a one standard deviation positive shock or innovation to FDI caused MFO to change by $0.04 \%$ in the short-run and $0.07 \%$ in the long-run. Other than own shock, InFDI had 0.043602 percent and 0.067681 percent effects on InMFO for periods 4 and 10 respectively representing both the short and long run. This result shows that foreign direct investment (InFDI) had a positive but minimal effect on manufacturing output growth (InMFO) in Nigeria.

Consequently, variance in InMFO caused by exchange rate (EXH) peaked at $5 \%$ in the long run from $4.3 \%$ in the short run, however making it the most source of fluctuation to manufacturing output growth (InMFO). Variance in InMFO caused by inflation rate (INF) peaked at 3.3\% in the long run from $2.3 \%$ in the short run, while variance in InMFO caused by manufacturing capacity utilization rate (CAPU) was $0.27 \%$ in the short run and $0.15 \%$ in the long run.

\section{Residual Diagnostic Tests}

Autocorrelation Test - The Breusch-Godfrey serial correlation LM test to test for serial correlation is presented on Appendix 7. Conducted at 5\% level, the probability of the Rsquared value of 0.86 is greater than 5 per cent; as such the null hypothesis for this test which states that there is no serial correlation in the model is accepted.

\section{Stability Test}

The Inverse roots of the AR polynomial graph on Appendix 8 have roots with modulus which are less than one and they lie within the unit circle; it means that the model is stable and the impulse response standard errors would be valid and the conclusions of the model would also be reliable. Therefore, the VAR model satisfies the dynamic stability condition.

\section{Policy Implications}

The study sought out to determine the effect of Foreign Direct Investment (FDI) on the manufacturing output growth in Nigeria, and its long-run relationship from 1981 to 2016. In achieving this, the study adopted the Vector Auto Regression (VAR) estimation technique and the Johansen Co-integration test to determine the effects of the variables on manufacturing output growth and its long-run relationship respectively.

Based on the research questions and objectives of the study, the VAR estimates from the impulse response function and variance decomposition test showed that foreign direct investment (FDI) had a positive but minimal effect on the manufacturing sector output growth (MFO) in Nigeria. The estimates from the variance decomposition showed that FDI inflows in Nigeria had a minimal effect on the Manufacturing sector output. This is implicative of the fact that FDI flow into Nigeria skewed towards the extractive industry, and other factors ranging 
from corruption, economic climate, poor infrastructure and insecurity. This is in support of Akinlo (2004) who posited that the minimal effect of FDI on the manufacturing sector could be attributed to the diversion of FDI benefits into Nigeria as well as mono-cultural foreign trade product by Nigeria.The capacity utilization rate was at a very low average of $0.15 \%$ which provided a clear insight into the low level of productivity in the manufacturing sector. This shows that Nigeria is yet to fully reap the benefits of FDI especially to the manufacturing sector.

\section{RECOMMENDATIONS}

Based on the findings and policy implications revealed from the analysis, the study therefore recommends the followings;

i. On the issue of corruption and diversion of funds from FDI inflows, agencies established to fight corruption such as Economic and Financial Crime Commission (EFCC) and Independent Corrupt Practices and Others Related Offences Commission (ICPC) should be seen to do their jobs to convince both foreigners and nationals that Nigeria is safe for investment.

ii. There should be a clear guide line in government policy regarding priority sectors that require foreign investments in Nigeria among which sectors like the manufacturing should be uppermost for development. The spill-over effects of the development of these sectors would be manifold increase in rate of employment, GDP and output, food supply and raw materials for industries (especially local ones) and foreign exchange earning etc.

iii. Productivity is the most desirable form of manufacturing output growth. Hence, there is need to encourage and accelerate the factors that affect productivity in the manufacturing sector of the country especially manpower and skills for as long as productivity is low, there cannot be a meaningful growth in the manufacturing sector. Hence, effort should be made to increase productivity especially in the manufacturing sector by improving in power supply and upgrading its technologies.

iv. Government should encourage the promotion of non-oil export products, as this will bring about reduction in the nation's level of dependence on the dominance of crude oil or what can be described as mono-cultural foreign trade product.

v. The government ought to come up with more friendly economic policies and business environment, which will attract FDI into virtually all the sectors of the economy.

\section{CONCLUSION}

The study examined the effect of Foreign Direct Investment (FDI) on the manufacturing sector output growth in Nigeria from 1981 to 2016. In achieving the objectives of the study, vector auto regression (VAR) estimation technique and Johansen co-integration test were employed for the nature of the effects and long-run relationship of the variables. The results of the analysis showed that FDI had a positive but poor effect and contribution on the manufacturing sector output growth. And it also showed there was a presence of long-run relationship between the variables in the model.

Therefore, on the basis of findings of this study, it was revealed that Nigeria is yet to fully reap the benefits of FDI, as its effects on manufacturing output growth at the moment is very little. However, hopes are rife that if these aforementioned challenges are tackled, the anticipated benefits of FDI will begin to manifest in our manufacturing industries in Nigeria.

\section{References}

Abu Maji\&Achegbulu, J. O. (2011). An investigation of the impact of foreign direct investment on economic growth in Nigeria. International Business and Management, 3(1), 232 - 238. 
Adejumo, A. Victor (2013). Foreign direct investments and manufacturing sector performance in Nigeria, 1970 2009. Australian Journal of Business and Management Research, 3(4), 39 - 56.

Adenikinju, A. (2003). Nigeria's imperative in the new World trade order, workshop report. African economic research consortium (AERC). Nairobi, Kenya and trade policy research and training (TPRTP), Department of economics, University of Ibadan: Ibadan.

Aghion, P. and Howitt, P. (1992). A model of growth through creative destruction. Econometrica, 60(2), 323-351.

Akinlo, A. E. (2004). Foreign direct investment and growth in Nigeria: an empirical investigation. Journal of Policy Modeling, 26, 627-639.

Akinmulegun, S. O. and Oluwole, F. O. (2013). An assessment of the Nigerian manufacturing sector in the era of globalization. American Journal of Social and Management Sciences, 5(1), 27 - 32.

Anowor, O. F., Ukweni, N. O., Ibiam, F. O. \&Ezekwem, O. S. (2013). Foreign direct investment and manufacturing sector growth in Nigeria. International Journal of Academic Scientific and Technical Research, 5, 41 - 54.

Ayanwale, A. B. (2007). FDI and economic growth: evidence from Nigeria. AERC Research Paper 165, African Economic Research Consortium, Nairobi.

Central Bank of Nigeria (2010). Statistical Bulletin, Vol. 21.

Central Bank of Nigeria (2016). Central Bank of Nigeria Statistical Bulletin, Vol. 27.

Chandran, V. G. R. \& Krishnan, G. (2008). Foreign direct investment and economic growth: the Malaysian experience. International Business Research, 1(3), 32 - 38.

Chenery, H. B. \&Strout, A. (1966). Foreign assistance and economic development. American Econ. Rev., 55, 679733.

Dipak, M., Ata, M. (2003). The African Manufacturing Firm, an Analysis Based on Firm Studies in Sub-Saharan Africa. Port Harcourt: Taylor and Francis Ltd.

Ebekozien, A., Ugochukwu, S. C. \&Okoye, P. U. (2015). An analysis of the trends of foreign direct investment inflows in the Nigerian construction sector.American International Journal of Contemporary Research, 5(1), 53 69.

Eboh, M. (2011). Systematic planning, marketing will attract FDI to Nigeria. Vanguard, p.14.

Ehijiele, E., Aguwamba, S. \&Nurudden, L. (2015). Foreign direct investment and its effect on the manufacturing sector in Nigeria. International Journal of Scientific and Research Publications, 6, 671 - 679.

Fabayo, J. (2003). FDI in Nigeria's manufacturing sector. In: O. J. Nnamani, C.M. Okafor, \& F.O. Odoko (Eds.), FDI in Nigeria (pp.177 -192). Proceedings of the 12th Annual Conference of the Regional Research units of the CBN, Kaduna, Nigeria: CBN.

Glass, A. J. \&Saggi, K. (2009). Multinational firms and technology transfer. ScandinavianJournal of Economics, 104(4), 495-513.

Grossman, Gene M. and Elhanan, Helpman (1991). Innovation and growth in the global economy. Cambridge: MIT Press.

Imoudu, E. C. (2012). The impact of foreign direct investment in Nigeria's economic growth; 1980 - 2009: evidence from the Johansen's co-integration approach.International Journal of Business and Social Science, 3(6), $122-134$.

Kiong, W. H. \&Jomo, K. S. (2005). Before the storm: the impact of foreign capital inflows on the Malaysia economy, 1966-1996. Journal of the Asia Pacific Economy, 10, 56-69.

$\mathrm{Li}, \mathrm{X}$. \& Liu, X. (2005). Foreign direct investment and economic growth: an increasingly endogenous relationship. World Development, 33, 393-407.

National Bureau of Statistics (2016). Nigerian gross domestic product report, Quarter two 2016, Abuja-Nigeria.

Nnanna, O. J., Englama, A. \&Odoko, F. O. (2004). Financial markets in Nigeria. (Eds.) Central Bank of NigeriaNigeria.

Obichukwu, U. I. (2013). The impact of industrial output on the economy of Nigeria, 1980 - 2010. Unpublished Project, Department of Economics, Faculty of Management and Social Sciences, Caritas University, Enugu State.

Okoli, T. T. \&Agu, O. C. (2005). Foreign direct investment flow and manufacturing sector performance in Nigeria.International Journal of Economics, Commerce and Management, 3(7), 412 - 428. 
Olsen, W. (2007). Pluralist methodology for development economics: the example of moral economy of Indian labour markets. Journal of Economic Methodology, 14(1), 57 - 82.

Opaluwa, D. Ameh, A. A., Alabi, J. O. \& Abdul, M. (2012). The effect of foreign direct investment on the Nigerian manufacturing sector.International Business and Management, 4(2), 140 - 148.

Orji, A., Anthony-Orji, O. I., Nchege, J. E. \&Okafor, J. (2015). Manufacturing output and foreign direct investment in Nigeria: a new evidence. International Journal of Academic Research in Economics and Management Sciences, 4(3), $16-28$.

Osisanwo, G. (2013). The macroeconomic effect of financial development on economicgrowth in Nigeria: A LongRun Analysis, 1970-2011. Journal of AfricanMacroeconomic Review, 4 (1) 227-245.

Patience, G. (2011). Impact of foreign direct investment on manufacturing output growth of West Africa. Africa Journal of Management and business, 6 (21) 67-77.

Romer, P. M. (1987). Increasing returns and long-run growth. J. Political Econ., 94(5), 1002-1037.

Romer, P. M. (1990). Endogenous technological change. Journal of Political Economy. Chicago: University of Chicago Press, 98(5), 71-102.

Sola, O., Obamuyi, T. M., Adekunjo, F. O. \&Ogunleye, E. O. (2013). Manufacturing performance in Nigeria: implication for sustainable development.Asian Economic and Financial Review, 3(9), 1195 - 1213.

Taiga, U. U. (2012). Manufacturing and economic growth in Nigeria - 1990 to 2010. Unpublished Project, Department of Social Sciences, College of Peace and Social Sciences, Salem University Lokoja, Kogi State.

UNCTAD (2015). World Investment Report. Investors Nationality: Policy Challenges, 1-232.

Uzoka C. I. (2012). The impact of foreign direct investment on Nigeria economic growth (1980 - 2010). Unpublished Project, Caritas University, Emene: Enugu.

World Bank (2004). World development indicators. Washington, D. C.: World Bank. 


\section{Appendix 1:}

\section{APPENDICES}

Data Presentation of Relevant Variables

\begin{tabular}{|c|c|c|c|c|c|}
\hline YEAR & $\underset{\text { Billion) }}{\text { FDI }}$ & $\begin{array}{c}\text { MFO } \\
\text { (ANBillion) }\end{array}$ & $\begin{array}{l}\text { EXH } \\
(\%)\end{array}$ & $\begin{array}{l}\text { INF } \\
(\%)\end{array}$ & $\begin{array}{c}\text { CAPU } \\
(\%)\end{array}$ \\
\hline 1981 & 542.3 & 26886 & 0.61 & 20.81 & 73.3 \\
\hline 1982 & 430.6 & 29086.8 & 0.67 & 7.7 & 63.6 \\
\hline 1983 & 364.4 & 31125.1 & 0.72 & 23.21 & 49.7 \\
\hline 1984 & 189.2 & 27124.6 & 0.76 & 17.82 & 43 \\
\hline 1985 & 485.6 & 37138.7 & 0.89 & 7.4 & 38.3 \\
\hline 1986 & 735.8 & 38650.3 & 2.02 & 13.7 & 38.8 \\
\hline 1897 & 2452.8 & 43216.1 & 4.02 & 9.7 & 40.4 \\
\hline 1988 & 1718.2 & 63519 & 4.54 & 61.2 & 42.4 \\
\hline 1989 & 13877.4 & 72896.6 & 7.39 & 44.7 & 43.8 \\
\hline 1990 & 4686 & 84270.3 & 8.04 & 3.6 & 40.3 \\
\hline 1991 & 6916.1 & 110599.4 & 9.91 & 23 & 42 \\
\hline 1992 & 14463.1 & 153467.9 & 17.3 & 48.8 & 38.1 \\
\hline 1993 & 29660.3 & 221229.7 & 22.05 & 61.3 & 37.2 \\
\hline 1994 & 22229.2 & 354664 & 21.89 & 76.8 & 30.4 \\
\hline 1995 & 75940.6 & 414125.8 & 21.89 & 51.6 & 29.29 \\
\hline 1996 & 111290.9 & 477947.8 & 21.89 & 14.3 & 32.48 \\
\hline 1997 & 110452.47 & 546712.5 & 21.89 & 10.2 & 30.4 \\
\hline 1998 & 80749 & 620203.5 & 21.89 & 11.9 & 32.4 \\
\hline 1999 & 92792.47 & 713821.7 & 92.69 & 0.2 & 34.6 \\
\hline 2000 & 115952.16 & 826025.4 & 102.11 & 14.5 & 36.1 \\
\hline 2001 & 132433.65 & 989114.4 & 111.94 & 16.5 & 42.7 \\
\hline 2002 & 225224.76 & 1127227 & 120.97 & 12.2 & 54.9 \\
\hline 2003 & 258388.61 & 1304071 & 129.36 & 23.8 & 56.5 \\
\hline 2004 & 248224.55 & 1516047 & 133.5 & 10 & 55.7 \\
\hline 2005 & 1921.21 & 1778730 & 132.15 & 11.6 & 54.8 \\
\hline 2006 & 41119.49 & 2082491 & 128.65 & 8.5 & 53.3 \\
\hline 2007 & 109161.26 & 2401193 & 125.83 & 6.6 & 53.38 \\
\hline 2008 & 124645.02 & 2761550 & 118.57 & 15.1 & 53.84 \\
\hline 2009 & 227093.29 & 3170823 & 148.88 & 13.9 & 55.14 \\
\hline 2010 & 137029.22 & 3578642 & 150.3 & 11.8 & 56.22 \\
\hline 2011 & 125668.71 & 4527445 & 153.86 & 10.3 & 55.68 \\
\hline 2012 & 240994.48 & 5588822 & 157.5 & 12 & 55.9 \\
\hline 2013 & 193089.72 & 7233323 & 157.31 & 7.96 & 55.8 \\
\hline 2014 & 253879.67 & 8685430 & 158.55 & 7.98 & 58 \\
\hline 2015 & 281998.14 & 8973773 & 193.28 & 9.55 & 55.7 \\
\hline 2016 & 267938.9 & 2679389 & 253.49 & 18.55 & 56.85 \\
\hline
\end{tabular}

Sources: CBN Statistical Bulletin, 2015; NBS, 2015. 
Appendix 2:

Unit Root Test Result

\begin{tabular}{|c|c|c|c|c|c|}
\hline Variable & $\begin{array}{c}\text { Order of } \\
\text { Stationarity }\end{array}$ & $\begin{array}{c}\text { ADF } \\
\text { Calculated }\end{array}$ & $\begin{array}{c}\text { ADF Critical } \\
\text { Value }\end{array}$ & $\begin{array}{c}\text { Order of } \\
\text { Integration }\end{array}$ & Decision \\
\hline \multirow{2}{*}{$M F O$} & At level & 0.017074 & -3.557759 & $1(0)$ & Not stationary \\
\cline { 2 - 6 } & $1^{\text {st } \text { difference }}$ & -11.22302 & -3.557759 & $1(1)$ & Stationary \\
\hline \multirow{2}{*}{$F D I$} & At level & -3.609367 & -3.544284 & $1(0)$ & Not stationary \\
\cline { 2 - 6 } & $1^{\text {st } \text { difference }}$ & -6.313990 & -3.548490 & $1(1)$ & Stationary \\
\hline \multirow{2}{*}{$E X H$} & At level & -1.385975 & -3.544284 & $1(0)$ & Not stationary \\
\cline { 2 - 6 } & $1^{\text {st } \text { difference }}$ & -3.994391 & -3.548490 & $1(1)$ & Stationary \\
\hline \multirow{2}{*}{$I N F$} & At level & -3.002961 & -3.574244 & $1(0)$ & Not stationary \\
\cline { 2 - 6 } & $1^{\text {st difference }}$ & -4.913925 & -3.562882 & $1(1)$ & Stationary \\
\hline \multirow{2}{*}{$C A P U$} & At level & -3.439698 & -3.548490 & $1(0)$ & Not stationary \\
\cline { 2 - 6 } & $1^{\text {st } \text { difference }}$ & -3.571627 & -3.548490 & $1(1)$ & Stationary \\
\hline
\end{tabular}

Computed at 5\% ADF critical value.

\section{Appendix 3:}

\section{VAR Lag Length Result}

\begin{tabular}{|ccccccc|}
\hline Lag & LogL & LR & FPE & AIC & SIC & HQ \\
\hline \hline 0 & -497.8152 & NA & 30604858 & 31.42595 & 31.65497 & 31.50187 \\
1 & -367.7265 & $211.3943^{*}$ & 43956.96 & 24.85790 & 26.23203 & 25.31339 \\
2 & -341.1475 & 34.88485 & $45058.77^{*}$ & 24.75922 & $27.27845^{*}$ & 25.59427 \\
3 & -306.3262 & 34.82127 & 34512.14 & 24.14539 & 27.80973 & 25.36002 \\
4 & -258.2167 & 33.07530 & 18235.81 & $22.70104^{*}$ & 27.51049 & $24.29524^{*}$ \\
\hline \hline * indicates lag order selected by the criterion \\
LR: sequential modified LR test statistic (each test at 5\% level) & & \\
FPE: Final prediction error \\
AIC: Akaike information criterion \\
SIC: Schwarz information criterion \\
HQ: Hannan-Quinn information criterion
\end{tabular}

Source:Author's Computation Using Eviews 4.0.

Appendix 4:

Co-integration Test Result

\begin{tabular}{|c|c|c|c|c|c|}
\hline $\begin{array}{l}\text { No. of } \\
\text { CE(S) }\end{array}$ & $\begin{array}{l}\text { Trace } \\
\text { stat. }\end{array}$ & $\begin{array}{c}0.05 \% \\
\text { CV }\end{array}$ & $\begin{array}{l}\text { No. of } \\
\text { CE(S) }\end{array}$ & $\begin{array}{l}\text { Max-Eigen } \\
\text { Stat. }\end{array}$ & $\begin{array}{c}0.05 \% \\
\text { CV }\end{array}$ \\
\hline None ${ }^{* *}$ & 63.48448 & 47.21 & None $* *$ & 35.07854 & 27.07 \\
\hline At most 1 & 28.40593 & 29.68 & At most 1 & 21.95990 & 20.97 \\
\hline At most 2 & 6.446038 & 15.41 & At most 2 & 6.248617 & 14.07 \\
\hline At most 3 & 0.197421 & 3.76 & At most 3 & 0.197421 & 3.76 \\
\hline
\end{tabular}

** denotes rejection of the hypothesis at the $5 \%$ level 


\section{Appendix 5:}

Impulse Response Result of InMFO to InFDI.

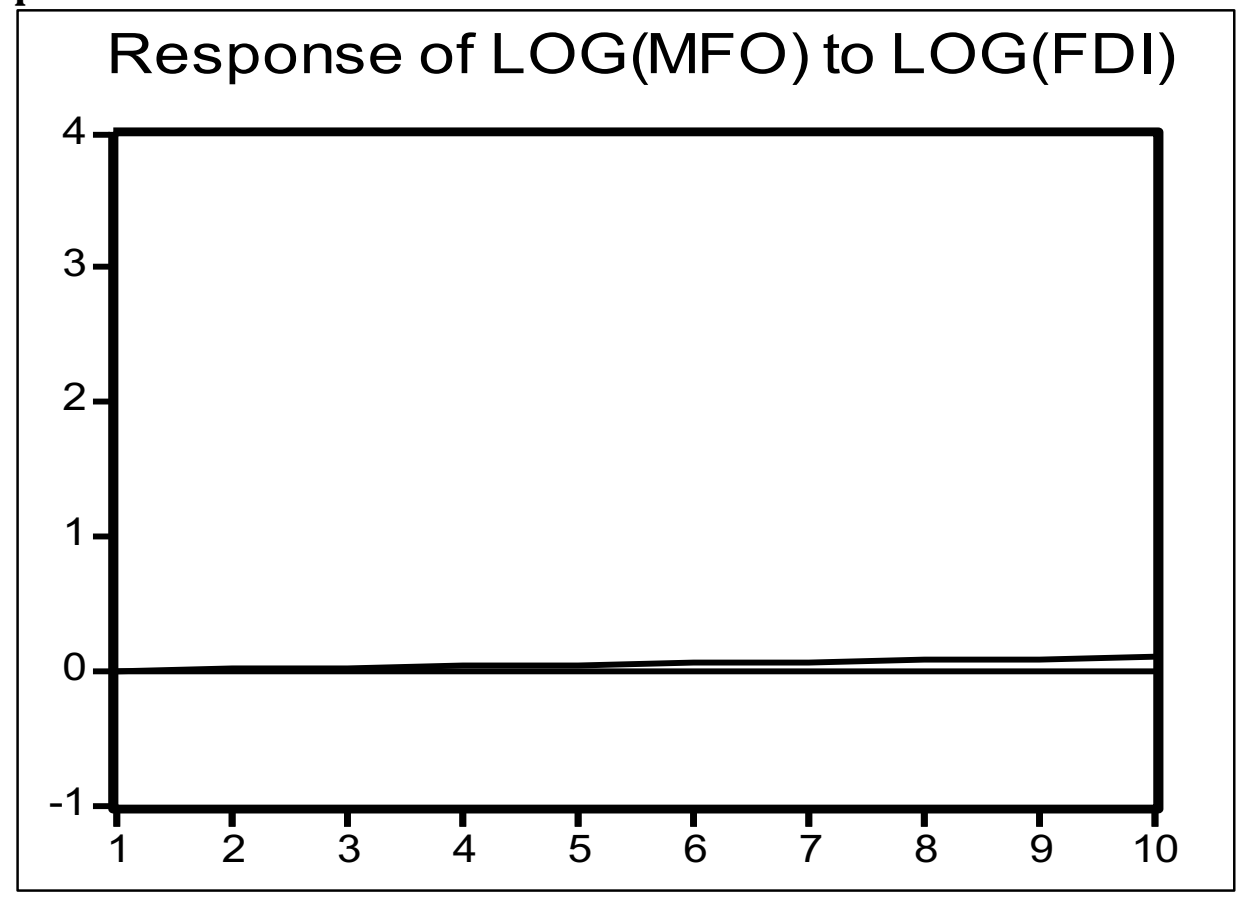

\section{Appendix 6:}

Results of Variance Decomposition Analysis of Manufacturing output growth (InMFO)

\begin{tabular}{|c|c|c|c|c|c|c|}
\hline Period & S.E. & LOG(MFO) & LOG(FDI) & $\boldsymbol{E X H}$ & $\boldsymbol{I N F}$ & $\boldsymbol{C A P U}$ \\
\hline 1 & 0.265432 & 100.0000 & 0.000000 & 0.000000 & 0.000000 & 0.000000 \\
2 & 0.689249 & 95.23232 & 0.010133 & 2.945843 & 1.262186 & 0.549522 \\
3 & 1.227281 & 93.69734 & 0.010297 & 4.062654 & 1.895531 & 0.334183 \\
4 & 1.824837 & 92.96974 & 0.043602 & 4.348606 & 2.371165 & 0.266889 \\
5 & 2.494501 & 92.46357 & 0.053861 & 4.563578 & 2.679145 & 0.239845 \\
6 & 3.251587 & 92.13035 & 0.056916 & 4.703878 & 2.898784 & 0.210071 \\
7 & 4.096907 & 91.86161 & 0.060840 & 4.823326 & 3.064558 & 0.189670 \\
8 & 5.031599 & 91.64692 & 0.063730 & 4.920700 & 3.193600 & 0.175054 \\
9 & 6.056706 & 91.46210 & 0.066181 & 5.001883 & 3.305172 & 0.164662 \\
10 & 7.174176 & 91.31209 & 0.067681 & 5.068589 & 3.395222 & 0.156418 \\
\hline
\end{tabular}

Source:Author's Computation Using Eviews 4.0.

\section{Appendix 7:}

\section{Breusch-Godfrey Serial Correlation LM Test Result}

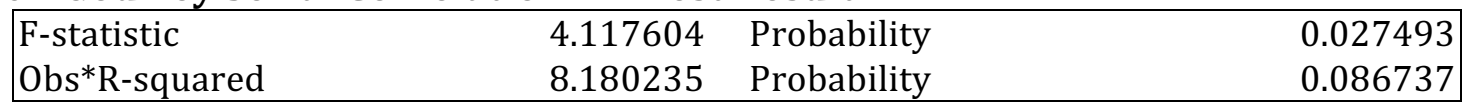

Source:Author's computation using Eviews 4.0. 


\section{Appendix 8:}

Stability Test Result

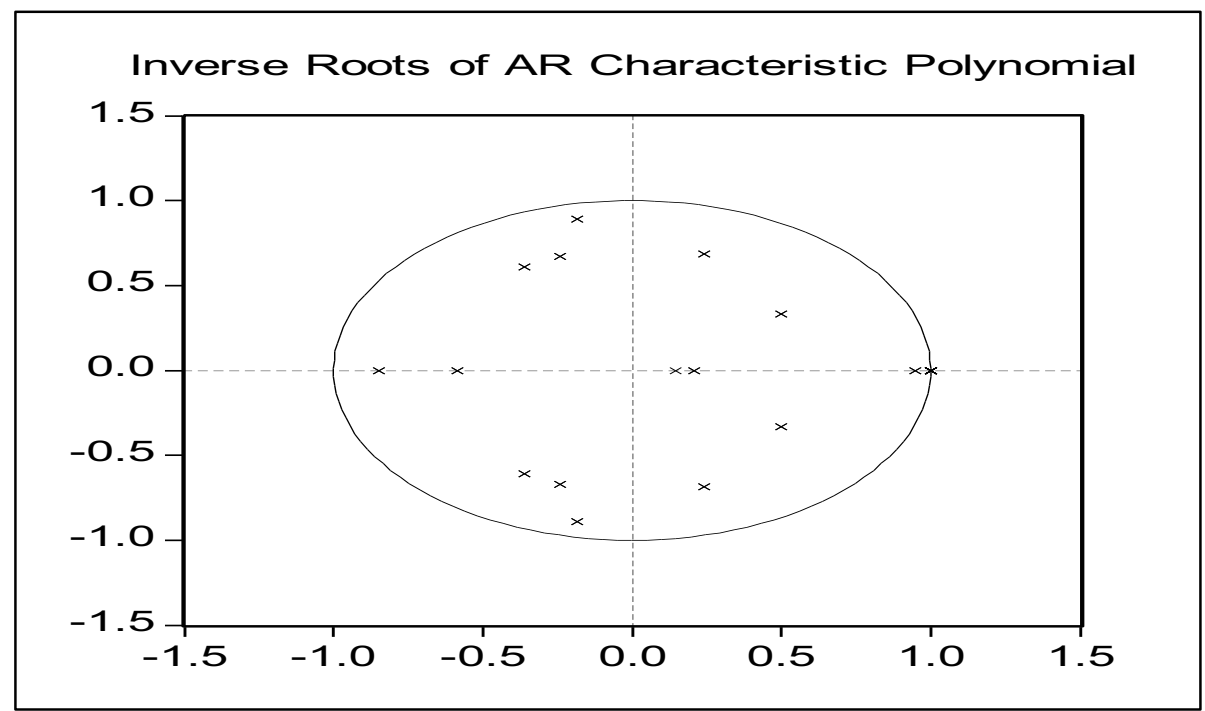

Source:Author's computation using Eviews 4.0. 